\begin{tabular}{|l|l|l|}
\hline \multicolumn{2}{|c|}{ PublisherInfo } \\
\hline \hline PublisherName & $:$ & BioMed Central \\
\hline \hline PublisherLocation & $:$ & London \\
\hline \hline PublisherImprintName & $:$ & BioMed Central \\
\hline \hline
\end{tabular}

\title{
Discovering metabolic loci
}

\begin{tabular}{|l|l|l||}
\hline \multicolumn{2}{|c|}{ ArticleInfo } \\
\hline \hline ArticleID & $:$ & 4684 \\
\hline \hline ArticleDOI & $:$ & $10.1186 /$ gb-spotlight-20030123-01 \\
\hline \hline ArticleCitationID & $:$ & spotlight-20030123-01 \\
\hline \hline ArticleSequenceNumber & $:$ & 36 \\
\hline \hline ArticleCategory & $:$ & Research news \\
\hline ArticleFirstPage & $:$ & 1 \\
\hline \hline ArticleLastPage & $:$ & 2 \\
\hline \hline & & RegistrationDate : 2003-1-23 \\
\hline ArticleHistory & $:$ & OnlineDate \\
\hline \hline ArticleCopyright & $:$ & BioMed Central Ltd2003-23 \\
\hline \hline ArticleGrants & $:$ & \\
\hline \hline ArticleContext & $:$ & 130594411 \\
\hline \hline
\end{tabular}




\section{Jonathan B Weitzman}

Email: jonathanweitzman@hotmail.com

Bacterial genomes often contain clusters of genes involved in secondary metabolite biosynthesis that are not expressed until induction by specific chemical or physical stimuli. In an Advanced Online Publication in Nature Biotechnology Zazopoulus et al. describe a high-throughput genome-scanning method to detect such clusters in bacterial genomes (Nature Biotechnology, 21 January 2003, doi;10.1038/nbt784). Genome sequence tags (GSTs) were screened against a database of microbial gene clusters of metabolic loci in order to rapidly identify novel metabolic loci. Zazopoulus et al. used the genome-scanning approach to screen actinomycete strains for genes involved in the biosynthesis of enedyine, a class of anti-tumor antibiotics. They found a conserved cluster of five genes. The putative 'warhead gene cassette' includes a polyketide synthase gene that may be involved in the formation of the reactive chromophore ring structures found in all enediynes.

\section{References}

1. The calicheamicin gene cluster and its iterative type I enediyne PKS.

2. Nature Biotechnology, [http://www.nature.com/naturebiotechnology]

This PDF file was created after publication. 